\title{
Sanctioned terror: economic sanctions and more effective terrorism
}

\section{Thomas Altmann ${ }^{1}$. Jason Giersch ${ }^{2}$}

Published online: 12 June 2021

(C) The Author(s) 2021

\begin{abstract}
The literature on unintended consequences of economic sanctions is well developed, but few studies have addressed terrorism in target states, and none have assessed whether that terrorism becomes more effective when sanctions are in place. In this study, we test whether economic sanctions lead to an increase in the lethality of terrorism. Using data from multiple sources, we find that while sanctions are unrelated to the rate of success of terrorist attacks, they are positively associated with the number of fatalities resulting from terrorist attacks. These findings further the need for policymakers to consider the consequences sanctions have on the target country populace.
\end{abstract}

Keywords Economic sanctions $\cdot$ Terrorism $\cdot$ International relations

\section{Introduction}

Beginning in 2018, the Trump administration engaged in a 'maximum pressure' campaign against Iran with the intent of weakening Supreme Leader Khamenei and demanded sweeping policy changes. Trump's own words demonstrate this attitude with the desire to implement the highest sanctions ever imposed on a country. In terms of its economy, sanctions on Iran have been catastrophic. After the mid-2018 imposition of sanctions, the entire Iranian economy has contracted $14 \%$, oil exports have been down by $88 \%$, and inflation has risen to $40 \%$ (Congressional Research Service 2020). These sanctions will likely cause turmoil for all social classes for several years to come.

Thomas Altmann

ctho@email.unc.edu

1 Department of Political Science, University of North Carolina at Chapel Hill, 362 Hamilton Hall, CB 3265, Chapel Hill, NC 27599, USA

2 Department of Political Science and Public Administration, University of North Carolina at Charlotte, Charlotte, NC, USA 
However, despite these economic consequences, Tehran has not acquiesced. Instead, the administration has only intensified its efforts toward nuclear weapon development (Congressional Research Service 2020). The ongoing stalemate between Iranian and Western leaders will continue to deteriorate the lives of the people living in Iran, possibly inspiring some to take action in the hope of political and economic relief or justice. Evidence from Iran already indicates that food security and healthcare access have decreased (Congressional Research Service 2020). Will tensions between government and opposition groups intensify as a result?

For nearly the past four decades, the USA has used economic sanctions as a preferred tool for its foreign policy. In accordance with the significant impacts of these policies, scholars have conducted a vast amount of research on sanctions using both qualitative and quantitative approaches. A considerable amount of this research on economic sanctions has focused on the efficacy of sanctions for producing desired policy changes by the target country, which are generally considered successful in achieving these changes (Bapat et al. 2013; Krustev 2010; Drezner 2003; Lacey et al. 2004).

However, over the past two decades, a growing body of research has been done on the unintended consequences of sanctions, which proves relevant for both the imposer and the imposed, especially when looking at violent terrorism. From this area of research, many unintended consequences from sanctions have emerged such as an increased infant mortality rate (Parker et al. 2016; Peksen 2011), reduced governmental respect for physical integrity rights (Peksen 2011), the breakdown of democracy (Peksen and Drury 2010), and increased criminalization of the state (Andreas 2005). While these are all critical consequences, sub-state violence stands as particularly meaningful, impactful, and salient for a nation on both a macro and micro level. Specifically, terrorism wreaks havoc on a state in virtually all aspects of society (Das 2019), a particularly total type of sub-state violence. Most importantly, terrorism rips apart individual lives, stresses the psyche of victims (North and Pfefferbaum 2004), ${ }^{10}$ and results in the loss of life. Primarily, research is needed that can be useful in the creation of policy guidelines that consider all possible consequences of economic sanctions. The present study examines one of the many possible consequences of economic sanctions: the increased effectiveness of terrorism.

\section{Previous research}

\section{Effectiveness of sanctions}

Almost half a century ago, scholars generally concluded that economic sanctions were ineffective in obtaining policy goals (Galtung 1967; Doxey 1971; Knorr 1975; Losman 1979). This consensus was changed when Hufbauer, Schott, and Elliott (1985) first published their study of a large sample of sanction episodes, which posited that the success rate was 34\%. Pape (1997) responded with evidence from the same data that the success rate of economic sanctions was actually closer to 5\%. Subsequently, Elliott (1998) responded, holding to her initial assertions with Pape (1998) once again issuing a rebuttal. Other studies find problems in the initial 
Hufbauer, Schott, and Elliott study by positing that when using logit estimation, the relationship between variables is insignificant, thus once again casting doubt on the efficacy of sanctions (Drury 1998). More recently, Shin et al. (2016) showed sanctions to have practically no impact on macroeconomic conditions in targeted countries, at least in terms of trade, foreign investment, and portfolio investments.

Research using more recent data gives greater attention to the roles that international institutions and severe costs on target states play in determining the success of an episode of sanctions (Bapat et al. 2013), a departure from the determinants used by previous studies. Over the development of the literature around terrorism's effectiveness, a shift has occurred in what determines success for a sanction episode. The research also now finds that the threat of sanctions instead of their imposition is an essential stage in obtaining success during a sanction episode (Bapat et al. 2013; Lacey and Nion 2004) with novel approaches such as game theory models, confirming that the threatening of sanctions can yield significant concessions (Drezner 2003).

However, much of the literature concluding that economic sanctions achieve policy goals overlooks the unintended consequences of sanctions. This omittance is problematic as even if concessions are made, the domestic and global costs might be too high to consider a particular sanction episode as successful. For example, if the USA can use sanctions to coerce Iran to comply with the Joint Comprehensive Plan of Action (JCPOA), but doing so increases transnational and domestic terrorism, it is hard to empirically or objectively conclude the sanctions yielded a 'success.' Thus, the unintended consequences of sanctions have received increased attention in research.

\section{Unintended consequences}

Recent research has examined various possible consequences of sanctions in the target country. For example, child mortality rates have been found to increase under sanctions, especially when the sanctions are costly or when the USA is the imposer (Peksen 2011). Parker et al. (2016) quantifies that infant deaths rose by at least $143 \%$ in the Democratic Republic of the Congo when sanctions were imposed.

Human rights decline as well when sanctions are imposed, typically in conjunction with the deterioration of democratic institutions within a target country (Peksen and Drury 2010). Primarily, sanctions seem to deteriorate the physical integrity rights of citizens, which include freedom from disappearances, extra-judicial killings, torture, and political imprisonment (Peksen 2009), with Wood (2008) confirming the findings. Gender seems to play a role in the process as well, with Drury and Peksen (2012) finding that economic sanctions reduce the level of respect for women's rights in the imposed country.

The literature also finds consequences extending beyond a sanction episode, particularly in the criminalization of the state. Sanctions can foster a symbiosis among political leaders, organized crime, and transnational smuggling networks, leading to transient corruption and crime (Andreas 2005). Naturally, the totality of these conditions during a sanction episode such as decreased public health and human rights 
and increased state criminalization creates a breeding ground for both transnational and domestic terrorism.

\section{Terrorism from sanctions}

According to strain theory, economic sanctions disrupt political and economic structures within a country, stressing the institutions of society in ways that make terrorist actions more likely (Agnew 2010; Nivette et al. 2017) and providing reasons for opposition groups to use terror to shake the authority of state leaders (Goodwin 2019; Tilly 2005). Several studies in the past decade provide evidence supporting the theory that the strain from sanctions leads to terrorism through aid shocks, heightened grievances, increased oppression, and a more active black market.

Ultimately, the greatest burdens resulting from sanctions tend to fall on regular citizens, and the poor in particular, intensifying deprivation and its social effects and inspiring discontents to take action (Choi and Luo 2013; Heffington 2017). Nielsen et al. (2011) provide a framework for armed conflict from a sanction episode type called aid shocks. These aid shocks, or severe decreases in international aid revenue, shift the balance of powers and induce violence by granting bargaining strength to potential rebels. Allen (2008), Nielsen et al. (2011), and Peksen (2009) all suggest that grievances resulting from sanctions induce civilians to turn to political violence. Moreover, multiple other studies connect sanctions to increased repression which in turn increases the amount and duration of terrorism (Daxecker and Hess 2013; Escriba-Folch 2011; Peksen 2009; Peksen and Drury 2010; Piazza 2008; Walsh and Piazza 2010).

Linking sanctions more directly to terror, Heffington (2017) finds that when costly sanctions are imposed on a country, frustration allows for easier recruiting and carrying out of attacks by domestic terrorist organizations due to costly economic hardship on regular citizens. Building on the work of Andreas (2005), Heffington (2017) argues that sanctions enhance terrorist operations by increasing access to black-market weapons. Both Choi and Luo (2013) and Choi (2014) argue that economic hardship in target states resulting from sanctions increases grievances among the poor, increasing the probability that some of them will support or engage in terrorism. In sum, there is ample empirical evidence suggesting that while economic sanctions may be intended to punish a country's leadership, a substantial portion of their impact will be felt by regular citizens, some of whom will become more likely to increase terrorist efforts. We suspect that those increased efforts will yield more fatalities.

\section{Measurements of effective terrorism}

There is a consensus in the literature that terrorists are rational actors (Abrahms 2008). Crenshaw (2014) argues that the decision to engage in terrorism is a calculation meant to obtain a specific goal through the use of collective action against civilian targets. Gambill (1998) finds terrorists use an expected utility analysis whereby they engage in terrorism because they perceive its chances of success as greater than 
alternative means of collective action. Krause (2013) posits that terrorist groups do not exclusively seek to affect government decisions and instead hope to achieve long-term ideological goals such as independence, revolution, societal transformation, and regime change. Therefore, the decision calculus made by terrorists, as predicted by the strategic model, would emphasize increasingly lethal civilian attacks because it would further their own goals through the predicted results of higher lethality (i.e., a more operationally powerful entity). Under both models of viewing terrorism, if a terrorist organization can produce more fatalities and more successful attacks, they would be furthering fear or long-term goals, and thus be a more successful organization.

This article applies novel operationalizations of the concept of effective terrorism in the context of economic sanctions. Young (2019) conducted a meta-analysis of 195 studies and observed that a majority used the number of attacks by terrorists in a given country year as the most common operationalization of terrorism. He noted that using the number of attacks as a measurement could be problematic because it depends on determining whether an instance counts as an attack. Counting the number of fatalities, he points out, addresses that problem. We use that measure as well as a measure of success rate.

\section{Hypothesis}

The extant literature around the conditions for countries subjected to economic sanctions, especially when costly, suggest that social strain will intensify (Agnew 2010) as the economic hardship (Choi and Luo 2013), political repression (Walsh and Piazza 2010), and access to black-market goods all increase (Andreas 2005). Thus, we hypothesize that when comparing country years, targeted nations having higher levels of economic sanctions will be more likely to experience more effective terrorism than those having lower or no levels of economic sanctions. More specifically, we expect the number of fatalities from terrorism to increase as insurgent groups become larger and more determined. However, increased activity will also produce more failed attempts, so while we expect fatalities in each country year to increase, we do not expect the rate of success to likewise increase. This hypothesis goes beyond previous literature by addressing not only if sanctions lead to more terrorism, but whether that terrorist activity is more deadly.

\section{Methods}

\section{Data}

This study uses country-year panel data from 1970 through 2009, including a total of 46 countries that had sanctions imposed on them in at least one of those years. The dependent variables measuring effectiveness of terrorist activity come from the Global Terrorism Database (GTD), which contains panel data on incidents of terrorism, defined by the GTD codebook as threatened or actual use of illegal force and 
violence by a non-state actor to attain a political, economic, religious, or social goal through fear, coercion, or intimidation. The incidents of terrorism were condensed into the total number of fatalities for one variable and the average success rate of attacks per year for the other. The study considers data on both transnational and domestic terrorism, but only through 2009.

The dataset used for the main independent variable is the Threat and Imposition of Economic Sanctions (TIES) dataset which also contains panel data on costly sanctions, defined by the TIES codebook as an increase of over 5\% inflation or unemployment and drastic reductions in trade relationships; data for non-costly sanctions were purged. Data for covariates used in the empirical model come from multiple sources. Civil war data come from Correlates of War's (CoW) intrastate war database (Sarkees and Wayman 2010); democracy, GDP, population, political repression, and human rights data come from the Quality of Government (QoG) time-series dataset (Dahlberg et al. 2020). All of the datasets were combined by country year to run statistical operations and test the hypothesis.

\section{Variables}

Our first operationalization of terrorism effectiveness is the total number of fatalities in a given country during each year. Heffington (2017) contends this method of measuring terrorism is inappropriate; however, this article is testing the effectiveness of terrorist attacks, and thus total fatalities from terrorism are the appropriate operationalizations. As Young (2019) finds, counting fatalities could be the superior operationalization due to being less susceptible to underreporting bias. Moreover, fatalities are directly linked to the physical operational means of the terrorist organization, meaning if they are producing more fatalities they can engage in more deadly and salient attacks (Krause 2013), thus producing more fear or achieving long-term goals.

The second operationalization was measured as the average success rate of incidents for a country in a given year. The GTD includes records of successful attempts at assassination, armed assault, bombing/explosion, hijacking, hostage taking, facility/infrastructure attacks, and unarmed assault. Each terrorist event is coded either 0 for failed attempts or 1 for successful ones, not in terms of the political goals but rather the immediate physical objective. Our measure is an average of these scores by country year. Higher values indicate that acts of terrorism were more successful in a given country in a given year. While Heffington (2017) uses the count of attacks to measure terrorist effectiveness, we choose to use success rate in order to account for attempts made. We chose these two operationalizations (fatalities and average success rate of attacks) to approach the abstract concept of terrorism effectiveness from two different, yet important methods to account for the fact that an organization may be effective in one way but not another.

The main independent variable being measured is costly economic sanctions as defined by the TIES codebook and is an interval-level variable. Only costly or severe economic sanctions are considered as we interpret the theoretical arguments of relational processes and indirect war to mean that there is little reason for people 
to change behavior under merely symbolic sanctions, but costly sanctions can be very disruptive. Economic conditions that produce terrorism would be most likely to occur in response to the costliest sanctions. Furthermore, sanctions are particularly costly at the onset of the first year of imposition and decrease for each year during the sanction episode (Heffington 2017); thus, the first year of the sanction episode is coded one and each consecutive year is multiplied by 0.9 until the episode has concluded or new sanctions are imposed, which is then coded zero, and yields a decay rate variable.

There are several covariates included in the empirical model. Civil war as a binary variable is included for its association with an increase in terrorism (Findley and Young 2012) and is coded as one if there is a civil war present in that year and zero if there is not a civil war. The theoretical argument also emphasizes political repression as inducing terrorism; therefore, we include political repression as a covariate according to the Political Terror Scale from Amnesty International in the QoG dataset. Moreover, political repression might influence the dependent variables as it could be a result of sanctions (Walsh and Piazza 2010; Wood 2008). Another covariate included in the model is democracy measured by the Freedom House Polity score on a range of 1-10 in the QoG dataset, which is imputed for values for countries where Polity data is missing. Democracy is included due to democracies suffering from higher levels of terrorism (Abadie 2006). General country economic development is accounted for with a natural logged measure of real GDP per capita from the Maddison Historical Studies (MHS) in the QoG dataset, which might influence how well a state can fight terrorism and affect the dependent variable (see Choi 2015). Finally, population (natural logged), measured by the World Bank's World Development Indicators (WDI) from the QoG dataset, is included as larger countries are more likely to experience higher levels of terrorism (Eyerman 1998) (Table 1).

\section{Analytic strategy}

In his meta-analysis, Young (2019) identified various regression techniques within the literature on terrorism. He found that a negative binomial regression was the most common modeling technique used in quantitative data analysis of counts of terrorism such as fatalities or number of attacks. Moreover, the results of Drakos

Table 1 Descriptive statistics

\begin{tabular}{lcclll}
\hline Variable & $\mathrm{n}$ & Mean & $\begin{array}{l}\text { Standard } \\
\text { Deviation }\end{array}$ & Min & Max \\
\hline Terrorism (fatalities) & 1241 & 67.5 & 344 & 0 & 6665 \\
Terrorism (success rate) & 1241 & 0.53 & 0.46 & 0 & 1 \\
Sanctions (decay) & 1241 & 0.14 & 0.28 & 0 & 1 \\
Political Terror Scale & 1241 & 2.99 & 1.11 & 1 & 5 \\
Population (logged) & 1241 & 16.7 & 1.53 & 13.18 & 21.01 \\
GDP per capita (logged) & 1241 & 8.37 & 1.14 & 6.54 & 10.84 \\
Level of Democracy & 1241 & 4.60 & 3.28 & 0.25 & 10 \\
Civil War & 1241 & 0.13 & 0.34 & 0 & 1 \\
\hline
\end{tabular}


and Gofas (2006) and Findley and Young (2012) found that a zero-inflated negative binomial regression can be used to deal with underreporting bias within databases of terrorism. However, Young (2019) found that Bayesian statistical models are not common in the quantitative study of terrorism, but highlights their multiple advantages such as when there is missing data (Honaker et al. 2011), a lower reliance on $\mathrm{p}$ values when communicating a range of likely values (Kruschke 2010) more easily modeled multilevel data structures (Gelman and Hill 2006), and ability to be updated and replicated easily when new data are provided (Kruschke 2011).

The hypothesis was tested for the first operationalization of the dependent variable (fatalities) with a conditional random-effects negative binomial regression (NBR) and multilevel mixed-effects negative binomial regression (MMNBR). The second operationalization (success rate) was tested with a Tobit regression model to account for its censored range (0 to 1$)$.

\section{Results}

The results provide evidence that sanctions lead to more effective terrorism within a target count when measuring total fatalities, but not average success rate. Table 2 displays these results. Model 1 presents results for the first operationalization measured by total fatalities using a random-effects NBR. Model 2 also presents results for the first operationalization but using a MMNBR. Model 3 presents results for the second operationalization using a RE linear regression, controlling for all covariates. All models were significant overall at the 0.001 level. Table 2 also shows the log likelihood for Model 1 and Model 2 and R-squared value for Model 3.

Model 1 shows a positive coefficient for the main independent variable that indicates that a one-unit increase in sanctions is associated with an increase in the $\log$ of the fatalities from terrorism count of 0.409 , controlling for all the covariates. Model 1 fits the data around clusters of country, thereby accounting for vast

Table 2 Regression results

\begin{tabular}{|c|c|c|c|c|c|c|}
\hline & \multicolumn{4}{|c|}{ DV: Fatalities from terrorism } & \multirow{2}{*}{\multicolumn{2}{|c|}{$\frac{\text { DV: Success rate }}{\text { Model 3: Tobit }}$}} \\
\hline & \multicolumn{2}{|c|}{ Model 1: cNBR } & \multicolumn{2}{|c|}{ Model 2: MMNBR } & & \\
\hline & Coefficient & S.E & Coefficient & S.E & Coefficient & S.E \\
\hline Sanctions (decay) & $.379 * *$ & $(.133)$ & $.781 \dagger$ & $(.436)$ & .142 & $(.133)$ \\
\hline Political Terror Scale & $.413 * * *$ & $(.053)$ & $1.13 * * *$ & $(.102)$ & $.169 * *$ & $(.049)$ \\
\hline Population (logged) & $.147 * * *$ & $(.033)$ & $.404 * * *$ & $(.107)$ & $.119^{*}$ & $(.055)$ \\
\hline GDP per capita (logged) & .046 & $(.048)$ & $-.309 *$ & $(.143)$ & -.042 & $(.070)$ \\
\hline Level of Democracy & $.140 * * *$ & $(.018)$ & $.081 *$ & $(.047)$ & $.066^{* *}$ & $(.020)$ \\
\hline Civil War & $.510 * * *$ & $(.108)$ & $1.66 * * *$ & $(.273)$ & $.355 * *$ & $(.111)$ \\
\hline Constant & $-14.26^{* * *}$ & $(.681)$ & $-14.85^{* * *}$ & $(2.03)$ & -2.138 & $(1.04)$ \\
\hline Log Likelihood & -3409 & & -3409 & & -788 & \\
\hline $\mathrm{n}$ & 1228 & & 1241 & & 1241 & \\
\hline
\end{tabular}

$\dagger<.1 * p<.05, * * p<.01, * * * p<.001$; one-tailed tests 
differences between each specific condition within a target county with a randomeffects model. These results in Model 1 support the hypothesis that sanctions increase the effectiveness of terrorism. Model 2 uses a MMNBR which accounts for both fixed effects and random effects within the model, while also using the group variable of country for the hierarchy structure. Both Model 1 and Model 2 use year as the exposure variable explaining the amount of exposure over which the dependent variable of fatalities was observed for each observation of country over 39 years. The results in Model 2 provide additional evidence supporting the hypothesized relationship, although at a more forgiving level of statistical significance (0.10). To test the endurance of the association, we used a one-year lagged dependent variable in an additional model, the results of which appear in the appendix (Table 3). Even under this additional scrutiny, the results still support the hypothesis. In Model 3, the main independent variable has a coefficient that is positive but not statistically significant.

Across the three models, the other independent variables showed, overall, statistically significant associations in the directions we would expect. Political terror, population size, level of democracy, and civil war all had positive coefficients with the two dependent variables. The coefficient for GPD per capita was only statistically significant in the second model, but in all three it was negative, as we expected it to be.

\section{Discussion}

The hypothesis held up under Model 1 and Model 2, but not Model 3. Therefore, for the total fatalities dependent variable, we reject the null hypothesis and find that when sanctions are imposed on a country, the number of fatalities from terrorism tends to increase. However, under Model 3, which controls for all the same covariates, we find no statistically significant relationship between sanctions and the average success rate of attacks.

The fact that fatalities are associated with sanctions, but success rate is not, deserves some attention. It is our contention that costly sanctions inspire terrorists to become more aggressive. This aggression leads to more fatalities, but it might also lead to attempts at terrorism with smaller odds of success. In other words, the improved effectiveness of terrorism resulting from sanctions is nuanced because emboldened actors will cause more deaths but also the occasional failed attempt. The imposition of sanctions, therefore, can lead to more terrorist efforts, some of which increase the number of fatalities and some that do not.

Recent research has uncovered new explanations for terrorism success. One factor seems to be the use of suicide bombers. Terrorist groups find this strategy useful against targets both hard (Piazza 2020) and soft, especially when perpetrated by women (Alakoc 2020). It is possible that sanctions place a burden on the poor (Choi 2014, Choi and Luo 2013) relative to elites and those who can more easily pivot to other economic opportunities (Shin 2016), which leads to the most desperate and lethal, if not always successful, methods available to terrorists. 


\section{Implications}

These results from the models have implications for policymakers when imposing sanctions upon a country. Previous literature has already established that sanctions lead to an increase in terrorism, but the results from this study further emphasize the implications of Andreas (2005) that the operational capacity of terrorist organizations may increase as a result of increased access to black-market goods. If sanctions are imposed, terrorist organizations might gain more clout in the target country, therefore increasing state deterioration by their increased recruiting and trade for weapons. An increase in the effectiveness of terrorism creates a host of problems for the government and citizenry such as increased state repression, loss of civilian life, and economic and social destabilization. Therefore, the policy challenges for countries such as the USA are to implement sanctions in a way that prevent increased black-market access and to engage in multilateral intervention to prevent singular targeting by terrorist organizations that increases foreign resentment by the home population. Such approaches could prevent terrorism from becoming more effective when sanctions are imposed by cutting the increased operational capacity of terrorists.

Furthermore, a more radical implication is that nations should shift away from sanctions, especially costly sanctions, as the cornerstone of their foreign policy. Returning to the example of Iran, the severe economic consequences the country is currently experiencing and causing it to slide into depression would mean terrorist activity could spike and be more effective. Future research should examine the circumstances under which the governments of the countries targeted by sanctions experience especially high degrees of terrorism effectiveness in order to help policymakers shape their decisions regarding sanctions in ways that minimize these unintended consequences.

In the literature on sanctions, this study also furthers the need for policymakers and researchers to consider such unintended consequences of sanctions as a determinant of success for a sanction episode. It is difficult for a policymaker or researcher to label the sanctions on Iran a success even if Iran made the concession to return to the JCPOA if terrorist organizations can operate more effectively as a consequence. The results also further emphasize the value of the line of research that links sanctions to terrorism.

\section{Conclusion}

This study sought to place terrorism in the target country more firmly in the group of unintended consequences of economic sanctions in the literature on international relations. More specifically, this study sought to conduct the first empirical research on whether economic sanctions lead to terrorist activity becoming more deadly by increasing the operational capacity of the organization. The study used strain theory to address this question and panel data on 46 countries for over three decades. The models developed by this study using the data combine a number of techniques to deliver results that provide additional evidence of the unintended consequences of sanctions. Two models yielded results that support the hypothesis when measuring 
the total fatalities from terrorist attacks. However, the models that measured terrorism as the average success rate of terrorist attacks were not conclusive. Andreas (2005) showed that sanctions can increase the criminalization of the state which leads to increased black-market access and thus higher operational capacity for terrorist organizations. Therefore, within the literature, the results of this study show not only that economic sanctions can increase terrorism in a target country, but that the terrorist activity is more salient and deadly, thus being even more relevant as an unintended consequence. This study is also relevant for the Biden administration's reliance on economic sanctions for foreign policy. To be clear, this article does not seek to indict the Biden administration, but rather to critique the strategy of economic sanctions overall as a tool future presidents will likely use frequently when dealing with countries that threaten American interests.

\section{Limitations}

The literature identifies a major methodological limitation in the applied study of terrorism which is underreporting bias. Drakos and Gofas (2006) find that many databases used for terrorist attacks do not represent the true number of terrorism incidents. They further find that there can be excessive zeros (a zero-inflated negative binomial regression can account for this) within the data and a correlation between increased level of polity and increased terrorist activity, which are characteristics caused by underreporting bias. The authors identify mitigation tactics by addressing level of polity, which this study does across all models by controlling for the covariate of level of democracy, but we must remain cautious due to a potential discrepancy in actual and observed terrorist incidents.

The models could also be confounded by the difference between domestic and international terrorism. The first dependent variable measuring terrorism as fatalities counts the total number of deaths from terrorist attacks per country by a particular year and does not account for whether the attacks are international or domestic. Therefore, it is hard to know in the models if the incidents are occurring due to sanctions on the country where the incidents occurred, or an international terrorist organization is conducting attacks against the target nation in no relation to sanctions. These limitations are explored by Young (2019), who finds that caution must be used when including both domestic and transnational terrorist incidents within the data. Moreover, the models do not account for terrorist organizations that are 'state-less' and do not rely on a home country. Furthermore, the first and second dependent variables do not account for asymmetric warfare leading to success or a different type of attack entirely that does not use conventional warfare means. For example, the models would not take into account cyberterrorism which can have severe effects on a target or international country. In other words, fatalities and success rate of attacks are not the only ways terrorists can disrupt a nation.

The results for Model 3 also have the implication that on average, the success rate of terrorist attacks does not increase due to sanctions. This is problematic for the hypothesis because we would expect for attacks to become more successful if the operational capacity of terrorists increases. Therefore, the results of the first two models are 
limited to an extent by the operational capacity only increasing in the way of fatalities from attacks. Moreover, due to fatalities from attacks increasing while the success rate does not could indicate that the two are not strongly correlated with each other. We suspect that this discrepancy is due to terrorist groups becoming more aggressive, leading to more deaths as well as more attempts at terror with mixed success rates.

\section{Future research}

Future research should focus on more ways to analyze whether terrorist organizations can become more effective in response to economic sanctions. The research could examine whether economic sanctions lead to terrorist organizations lasting longer as an entity within the target country. Future research should also look at different types of terrorism that can be present such as cyberterrorism, which has yet to be addressed entirely in the context of being a consequence of economic sanctions. Returning to the example of Iran presented at the beginning of this article, no research has yet been done on a case study of economic sanctions and terrorism. Iran would be a prime candidate for a case study since it is extremely relevant to current global affairs and also because the sanctions imposed by the Trump administration are some of the costliest ever implemented (Congressional Research Service 2020). Therefore, if a causal relationship were to exist between economic sanctions and terrorism, it should be found there first. Beyond terrorism as a result of sanctions, future research on economic sanctions based on the results of this study should further realize analysis on sanction episodes in context of ordinary citizens as opposed to decisions made by the elite regarding policy.

\section{Appendix}

See Table 3.

Table 3 Lagged dependent variable negative binomial regression results

\begin{tabular}{lcc}
\hline & \multicolumn{2}{c}{$\begin{array}{l}\text { DV: Terrorism fatalities } \\
\text { lagged 1 year }\end{array}$} \\
\cline { 2 - 3 } & Coefficient & S.E \\
\hline Sanctions (decay) & $.373 *$ & $(.171)$ \\
Political Terror Scale & $.289 * * *$ & $(.057)$ \\
Population (logged) & $.088^{* *}$ & $(.033)$ \\
GDP per capita (logged) & .000 & $(.055)$ \\
Level of Democracy & $.053 * *$ & $(.020)$ \\
Civil War & .147 & $(.143)$ \\
Constant & -1.79 & \\
Log Likelihood & -788 & \\
$\mathrm{n}$ & 1241 & \\
\hline$* p<.05 ; * p<.01 ; * * p<.001 ;$ one-tailed tests.
\end{tabular}


Acknowledgements The authors thank the Department of Political Science at the University of North Carolina at Chapel Hill for their financial support to make this article open access.

\section{Declarations}

Conflict of interest On behalf of all authors, the corresponding author states that there is no conflict of interest.

Open Access This article is licensed under a Creative Commons Attribution 4.0 International License, which permits use, sharing, adaptation, distribution and reproduction in any medium or format, as long as you give appropriate credit to the original author(s) and the source, provide a link to the Creative Commons licence, and indicate if changes were made. The images or other third party material in this article are included in the article's Creative Commons licence, unless indicated otherwise in a credit line to the material. If material is not included in the article's Creative Commons licence and your intended use is not permitted by statutory regulation or exceeds the permitted use, you will need to obtain permission directly from the copyright holder. To view a copy of this licence, visit http://creativecommons.org/licen ses/by/4.0/.

\section{References}

Abadie, Alberto. 2006. Poverty, Political Freedom, and the Roots of Terrorism. American Economic Review 96 (2): 50-56.

Abrahms, Max. 2008. What Terrorists Really Want: Terrorists Motives and Counterterrorism Strategy. International Security 32 (4): 78-105.

Agnew, R. 2010. A General Strain Theory of Terrorism. Theoretical Criminology 14 (2): 131-153.

Alakoc, Burcu Pinar. 2020. Femme Fatale: The Lethality of Female Suicide Bombers. Studies in Conflict \& Terrorism 43 (9): 796-814.

Allen, Susan. 2008. The Domestic Political Costs of Economic Sanctions. Journal of Conflict Resolution 52 (6): 916-944.

Andreas, Peter. 2005. Criminalizing Consequences of Sanctions: Embargo Busting and Its Legacy. International Studies Quarterly 49 (1): 335-360.

Bapat, Navin A., Tobias Heinrich, Yoshiharu Kobayashi, and T. Clifton Morgan. 2013. Determinants of Sanctions Effectiveness: Sensitivity Analysis Using New Data. International Interactions 39 (1): 79-98.

Choi, Seung-Whan. 2014. Causes of Domestic Terrorism: Economic Sanctions as a Violence Trigger Structure. Korean Journal of International Studies 12 (1): 137-159.

Choi, Seung-Whan. 2015. Economic Growth and Terrorism: Domestic, International, and Suicide. Oxford Economic Papers 67 (1): 157-181.

Choi, Seung-Whan., and Shali Luo. 2013. Economic Sanctions, Poverty, and International Terrorism: An Empirical Analysis. International Interactions 39 (2): 217-245.

Congressional Research Service. 2020. Iran Sanctions. Report No. RS30871. https://fas.org/sgp/crs/mideast/ RS20871.pdf.

Crenshaw, Martha. 2014. Terrorism Research: The Record. International Interactions 40 (4): 556-567.

Dalhberg, et al. 2020. The Quality of Government Basic Dataset, version Jan 20. The Quality of Government Institute: University of Gothenburg.

Das, Ramesh. 2019. The Impact of Global Terrorism on Economic and Political Development: Afro-Asian Perspectives. Bingley: Emerald Group Publishing.

Daxecker, Ursula, and Michael Hess. 2013. Repression hurts: Coercive government responses and the demise of terrorist campaigns. British Journal of Political Science 43 (3): 559-577.

Doxey, Margaret. 1971. Economic Sanctions and International Enforcement. Oxford: Oxford University Press.

Drakos, Konstantinos, and Andreas Gofas. 2006. The Devil You Know but Are Afraid to Face: Underreporting Bias and its Distorting Effects on the Study of Terrorism. Journal of Conflict Resolution 50 (5): $714-735$. 
Drezner, Daniel. 2003. The Hidden Hand of Economic Coercion. International Organization 57 (3): 643-659.

Drury, A Cooper. 1998. Revisiting Economic Sanctions Reconsidered. Journal of Peace Research 35 (4): 497-509.

Drury, A. Cooper, and Durson Peksen. 2012. Women and economic statecraft: The negative impact international economic sanctions visits on women. European Journal of International Relations 20 (2): 463-490

Elliott, Kimberly. 1998. The Sanctions Glass: Half Full or Completely Empty? International Security 23 (1): 50-65.

Escriba-Folch, Abel. 2011. Authoritarian Responses to Foreign Pressure: Spending, Repression, and Sanctions. Comparative Political Studies 45 (6): 683-713.

Eyerman, Joe. 1998. Terrorism and Democratic States: Soft Targets or Accessible Systems. International Interactions 24 (2): 151-170.

Findley, Michael, and Joseph Young. 2012. Terrorism and Civil War: A Spatial and Temporal Approach to a Conceptual Problem. Perspectives on Politics 10 (2): 285-305.

Galtung, Johan. 1967. On the Effects of International Economic Sanctions: With Examples from the Case of Rhodesia. World Politics 19 (3): 378-416.

Gambill, Gary. 1998. The Balance of Terror: War by Other Means in the Contemporary Middle East. Journal of Palestine Studies 28 (1): 51-66.

Gelman, Andrew, and Jennifer Hill. 2006. Data Analysis Using Regression and Multilevel/Hierarchal Models. Cambridge: Cambridge University Press.

Goodwin, Jeff. 2019. The Causes of Terrorism. The Oxford Handbook of Terrorism, 253.

Heffington, Colton. 2017. Marked Targets: Coercive Diplomacy and Domestic Terrorism. Journal of Global Security Studies 2 (2): 123-136.

Honaker, James, Gary King, and Matthew Blackwell. 2011. Amelia II: A Program for Missing Data. Journal of Statistical Software 45 (7): 1-47.

Hufbauer, Gary, Jefferey Schott, and Kimberly Elliot. 1985. Economic Sanctions Reconsidered: History and Current Policy. Washington: Institute for International Economics.

Knorr, Klaus. 1975. The Power of Nations: The Political Economy of International Relations. New York: Basic Books.

Krause, Peter. 2013. The Political Effectiveness of Non-State Violence: A Two-Level Framework to Transform a Deceptive Debate. Security Studies 22 (2): 259-294.

Kruschke, John. 2010. What to Believe: Bayesian Methods for Data Analysis. Trends in Cognitive Sciences 14 (7): 293-300.

Kruschke, John. 2011. Introduction to Special Section on Bayesian Data Analysis. Perspectives on Psychological Science 6 (3): 272-273.

Krustev, Valentin. 2010. Strategic Demands, Credible Threats, and Economic Coercion Outcomes. International Studies Quarterly 54 (1): 146-174.

Lacey, Dean, and Emerson Niou. 2004. A Theory of Economic Sanctions and Issue Linkage: The Roles of preferences, Information, and Threats. Journal of Politics 66 (1): 25-42.

Losman, Donald. 1979. International Economic Sanctions: The Cases of Cuba, Israel, and Rhodesia. Albuquerque: University of New Mexico Press.

Nielsen, et al. 2011. Foreign Aid Shocks as a Cause of Violent Armed Conflict. American Journal of Political Science 55 (2): 219-232.

Nivette, A., M. Eisner, and D. Ribeaud. 2017. Developmental Predictors of Violent Extremist Attitudes: A Test of General Strain Theory. Journal of Research in Crime and Delinquency 54 (6): 755-790.

North, Carol, and Betty Pfefferbaum. 2004. The State of Research on the Mental Health Effects of Terrorism. Epidemiology and Psychiatric Sciences 13 (1): 4-9.

Pape, Robert. 1997. Why Economic Sanctions Do Not Work. International Security 22 (2): 90-136.

Pape, Robert. 1998. Why Economic Sanctions Still Do Not Work. International Security 23 (1): 66-77.

Parker, Dominic, Jeremy Foltz, and David Elsea. 2016. Unintended Consequences of Sanctions for Human Rights: Conflict Minerals and Infant Mortality. Journal of Law and Economics 59 (4): 731-774.

Peksen, Dursun. 2011. Economic Sanctions and Human Security: The Public Health Effect of Economic Sanctions. Foreign Policy Analysis 7 (3): 237-252.

Peksen, Dursun. 2009. Better or Worse? The Effect of Economic Sanctions on Human Rights. Journal of Peace Research 46 (1): 59-77.

Peksen, Dursun, and Cooper Drury. 2010. Coercive or Corrosive: The Negative Impact of Economic Sanctions on Democracy. International Interactions 36 (3): 240-264. 
Piazza, James. 2008. Incubators of terror: Do failed and failing state promote transnational terrorism? International Studies Quarterly 52 (3): 469-488.

Piazza, James A. 2020. Suicide Attacks and Hard Targets: An Empirical Examination. Defence and Peace Economics 31 (2): 142-159.

Sarkees, Meredith, and Frank Wayman. 2010. Resort to War: 1816-2007. Washington: CQ Press.

Shin, Geiguen, Seung-Whan. Choi, and Shali Luo. 2016. Do Economic Sanctions Impair Target Economies? International Political Science Review 37 (4): 485-499.

Tilly, Charles. 2005. Terror as Strategy and Relational Process. International Journal of Comparative Sociology 46 (1-2): 11-32.

Walsh, James, and James Piazza. 2010. Why Respecting Physical Integrity Rights Reduces Terrorism. Comparative Political Studies 43 (5): 551-577.

Wood, Reed. 2008. A Hand Upon the Throat of the Nation: Economic Sanctions and State Repression, 19762001. International Studies Quarterly 52 (3): 489-513.

Young, J.K. 2019. Measuring Terrorism. Terrorism and Political Violence 31 (2): 323-345.

Publisher's Note Springer Nature remains neutral with regard to jurisdictional claims in published maps and institutional affiliations. 